\title{
Fire Blight Disease Caused by Erwinia amylovora on Rosaceae Plants in Kyrgyzstan and Biological Agents to Control This Disease
}

\author{
Tinatin Doolotkeldieva, Saykal Bobusheva \\ Plant Protection Department, Faculty of Agriculture, Kyrgyz-Turkish Manas University, Bishkek, Kyrgyzstan \\ Email: tdoolotkeldieva@gmail.com
}

How to cite this paper: Doolotkeldieva, T. and Bobusheva, S. (2016) Fire Blight Disease Caused by Erwinia amylovora on Rosaceae Plants in Kyrgyzstan and Biological Agents to Control This Disease. Advances in Microbiology, 6, 831-851. http://dx.doi.org/10.4236/aim.2016.611080

Received: August 19, 2016

Accepted: September 11, 2016

Published: September 14, 2016

Copyright $\odot 2016$ by authors and Scientific Research Publishing Inc. This work is licensed under the Creative Commons Attribution International License (CC BY 4.0).

http://creativecommons.org/licenses/by/4.0/

\section{(c) (i) Open Access}

\begin{abstract}
Erwinia amylovora species were isolated from the blossoms, exudates, infected fruits, leaves and bent branches of diseased apple, pear and hawthorn trees, selected in the Chy, Osh and Jalal Abad regions. Biochemical and pathogenicity tests, alongside PCR analyses, were conducted to identify the local isolates of Erwinia amylovora. The alternative antagonistic microorganisms which combat bacterium $E$. amylovora were tested within in vitro and in vivo conditions. The results revealed the ability of Streptomyces antagonistic bacteria to decrease fire blight severity on pear and apple trees during the first stage of the fire blight disease in leaf tissues. Streptomyces strain C1-4 suppressed E. amylovora disease symptoms in the leaf tissues and excised apple and pear shoots. The incidence of fire blight on leaves was reduced by about $70 \%$ with two applications of bacterial antagonists. Further studies at different locations in Kyrgyzstan, using large scale application, would allow for stronger recommendations to be made, including studies and recommendations on their ability to prevent disease and to use them as main components in an integrated pest management program.
\end{abstract}

\section{Keywords}

Biological Control Agents, Fire Blight, Erwinia amylovora, Antagonistic Bacteria

\section{Introduction}

Fire blight, caused by the bacterium Erwinia amylovora, is an important disease affecting most types of Rosaceae plant and represents an enormous threat to fruit cultivation in many parts of the world. The host Rosaceous trees for Erwinia amylovora are pear, apple, quince, loquat, ornamental and wild plants (cotoneaster, pyracantha, stranvaesia, 
hawthorn, sorbus). According to EPPO (2012), E. amylovora is currently present in more than 50 countries worldwide [1].

It is a complex disease which passes its entire cycle in close association with the host plant, where it is able to infect fruit, leaf, shoot and flower tissue. Infected plant parts will, in all cases, cause sticky, amber-like drops of ooze, composed of viable bacteria in a polysaccharide matrix, to be formed on the blighted plant parts [2].

Erwinia amylovora is a gram-negative bacterium, described as such by Burrill in 1883 [1]. It has a wide geographical distribution and large economic importance. It is a quarantined organism in many countries, including in Europe and Asia. This bacterium leads both an epiphytic and endophytic life.

Many assays have been developed for the detection of the gram-negative bacterium Erwinia amylovora, as the causative agent of fire blight. Classical methods include plating on semi-selective media or serological assays like an enzyme-linked immunosorbent assay or immunofluorescence [3] [4].

Erwinia amylovora, the causative agent of fire blight, was identified independently from the common plasmid pEA29 by three different PCR assays with chromosomal DNA. PCR with two primers was performed with isolated DNA and with whole cells, which were directly added to the assay mixture. The oligonucleotide primers were derived from the ams region and the PCR product comprised the ams $B$ gene, which is involved in exopolysaccharide synthesis. The amplified fragment of $1.6 \mathrm{~kb}$ was analysed and the sequence was found to be identical for two E. amylovora strains [5].

Pathogenicity and virulence of the pathogen E. amylovora depend on different factors. However, probably the most essential reasons for differences in virulence between different strains of $E$. amylovora are the variation in the synthesis of exopolysaccharides (EPS) and the mechanism of the type III secretion system (T3SS) and associated proteins. One of these EPS is amylovoran which is the main constituent of bacterial ooze. Amylovoran is a polymer of a pentasaccharide repeating unit that generally consists of four galactose residues and one glucuronic acid residue [6] [7]. E. amylovora strains that do not have the capacity to produce amylovoran are non-pathogenic and are unable to spread in plant vessels [8]. Another EPS that is synthesized by E. amylovora is levan. Lack of levan synthesis can result in a slow development of symptoms in the host plant [9].

Koczan et al. [10] [11] discovered that the EPS of E. amylovora are also involved in biofilm formation, which enables the bacteria to attach to several surfaces and each other. They have suggested that biofilm formation plays an important role in the pathogenesis of E. amylovora, as their study showed that amylovoran is necessary for biofilm formation and that levan contributes to this biofilm formation.

Another important factor in pathogenicity is confined by the action of the T3SS (the type III secretion system). The T3SS of plant-pathogenic bacteria is mainly made out of $H R C$ proteins, encoded by HRP-conserved ( $H R C$ ) genes among plant-pathogenic bacteria and HRP proteins, encoded by hypersensitive response and pathogenicity (HRP) genes. In $E$. amylovora, $H R C$ and $H R P$ genes are clustered in a pathogenicity island 
which contains four regions: a $H R P / H R C$ region, an HRC effectors and elicitors region, an $H R P$-associated enzymes region and an island transfer region [12].

Fire blight is difficult to control, as it is able to rapidly spread in the plant and effective control methods are still lacking. Suppression of the blossom-blight phase of fire blight is a key point in the management of this destructive and increasingly significant disease in apple and pear trees [13]. Chemical control of fire blight is difficult, because there are few effective bactericides registered, while streptomycin (which is effective) and other antibiotics are not registered worldwide. According to some researchers, only copper fungicides can suppress this disease [14].

Scientists are attempting to find biological agents to use against this severely destructive disease, so in some parts of the world searches have been carried out for antagonist-microorganisms to use against fire blight. Biological control agents of fire blight have been found by applying, through spraying treatments, non-pathogenic bacteria, Bacillus subtilis or Pantoea agglomerans and plant extract, viz. Harmel (Peganum harmala L.), to open flowers in Egypt [15]. A talc-based formulation of Pantoea agglomerans strain Eh-24 was applied at 30\% and 100\% bloom on two pear orchards, which were selected from different locations in the Aegean Region in Turkey. The talc-based formulation of $P$. agglomerans strain Eh-24 reduced the percentage of blighted blossoms on pear orchards by between $63 \%$ and $76 \%$, approximately [16]. The Erwinia herbicola strain, Eh1087, established stable populations for at least 10 days post-application when sprayed onto apple blossoms in the orchard. This strain produced a broad spectrum, non-peptide, $\beta$-lactam antibiotic in vitro that was bactericidal for $E$. amylovora. Eh1087 suppressed E. amylovora disease symptoms in immature pear fruit, excised apple shoots and apple blossoms in a Canterbury orchard [17].

Under field conditions, Johnson et al. [18] found that early establishment of populations exceeding $10^{5} \mathrm{CFU}$ per blossom of $P$. fluorescens $P f A-506$ and $P$. agglomerans $E$ h C9-1 on pear blossoms suppressed establishment and growth of E. amylovora, thereby decreasing disease incidence. The incidence of fire blight on blossoms was reduced by about $60 \%$ with two applications of bacterial antagonists in experimental plots in the Pacific Northwest [19] and California [20]. The efficacy of biological control approached or equalled levels obtained with chemical control in many of the field trials [20].

As became evident, many scientists prefer dealing with the blossom blight phase of fire blight for the management of this disease. Biological control agents (BCAs) are now commercially available [21]. However, the effectiveness of BCA products for fire blight control was generally low and highly variable [22] [23]. Therefore, there is still a need for new species and strains of BCAs with novel mechanisms of action, which also fulfil the current strict authorization requirements in most countries for microbial bio-bactericides [24].

The first disease cases of fire blight in fruit trees were marked in several regions of Kyrgyzstan during the period of 2009-2013. The Phytosanitary Service of KR has examined 1235 ha in the Chui region, including 42.1 hectares of contaminated trees with fire blight. In the Issyk-Kul region, the first signs of symptoms of fire blight in fruit 
have been identified since July, 2012. In 2013, the disease spread to the eastern districts of the region. The first signs of symptoms similar to bacterial blight on pome trees in the forests of Southern Kyrgyzstan were sighted in 2008-2009 by the employees of the Plant Protection station, located in the city of Jalal-Abad.

The objective of this study was isolation and identification of E. amylovora in diseased parts of fruit trees and shrubs from the Rosaceae family, as well as the examination of the efficacy of alternative bactericides against bacterium $E$. amylovora under in vitro and in vivo conditions.

\section{Methods and Material}

\subsection{Plant Samples Collection}

Diseased pear and apple flowers, leaves and fruitlets showing necrotic/cankers characterizing symptoms (Figure 1) of fire blight were collected from trees and used for isolation of the causative bacterium (Table 1 ).
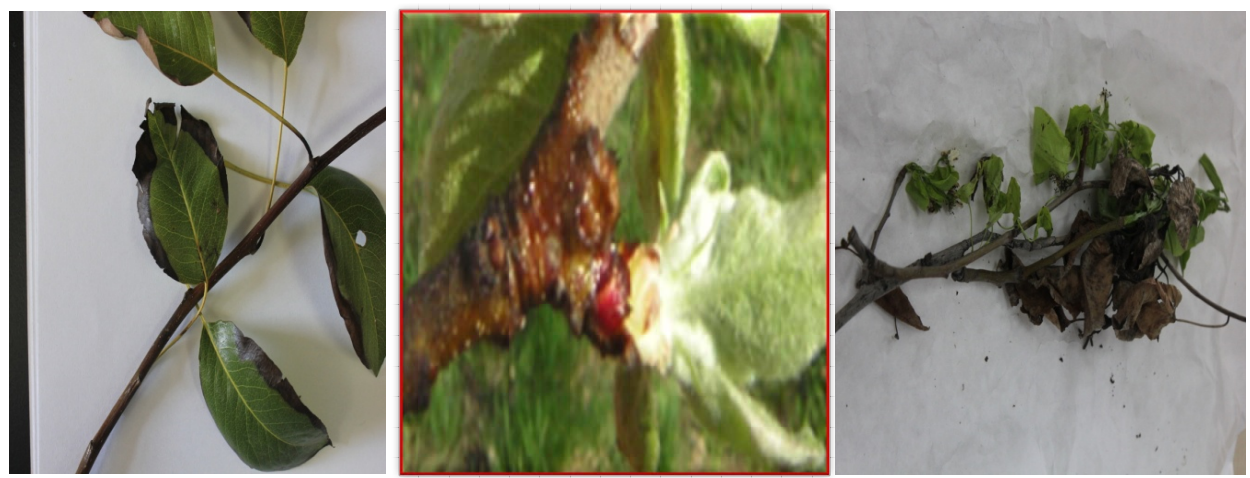

Figure 1. Diseased plant organs analyzed for isolation of Erwinia amylovora.

Table 1. Samples taken from diseased plants.

\begin{tabular}{llll}
\hline Time of sampling & Sampling place & Species of plants & Plant organs \\
\hline $\begin{array}{l}\text { The end of April } \\
\text { 2014, May 2015 }\end{array}$ & $\begin{array}{l}\text { Botanical Garden named } \\
\text { after Gareev, Bishkek city }\end{array}$ & $\begin{array}{l}\text { Different varieties of } \\
\text { apple and pear trees }\end{array}$ & $\begin{array}{l}\text { The young buds; } \\
\text { blooms with exudate }\end{array}$ \\
Kay, 2015 & $\begin{array}{l}\text { Karakol city, Issyk-Kul } \\
\text { province }\end{array}$ & $\begin{array}{l}\text { Different varieties of } \\
\text { apple and pear trees }\end{array}$ & $\begin{array}{l}\text { The young buds; } \\
\text { blooms with exudate }\end{array}$ \\
June, 2015 & $\begin{array}{l}\text { Fruit farming of Nookat } \\
\text { district, Osh province }\end{array}$ & $\begin{array}{l}\text { Different varieties of } \\
\text { apples and pears }\end{array}$ & $\begin{array}{l}\text { The affected shoots } \\
\text { and leaves }\end{array}$ \\
June, 2015 & $\begin{array}{l}\text { Fruit farming of Karasuu, } \\
\text { Fruit farming }\end{array}$ & $\begin{array}{l}\text { Different varieties of } \\
\text { apples and pears }\end{array}$ & $\begin{array}{l}\text { The affected shoots } \\
\text { and leaves }\end{array}$ \\
June, 2015 & $\begin{array}{l}\text { Arslan bob walnut forests, } \\
\text { Jalal Abad }\end{array}$ & Hawthorn & $\begin{array}{l}\text { The affected shoots } \\
\text { and leaves }\end{array}$ \\
Fay, 2015 & $\begin{array}{l}\text { Fruit farming of Suzak dis- } \\
\text { trict, Osh province }\end{array}$ & $\begin{array}{l}\text { Different varieties of } \\
\text { apples }\end{array}$ & $\begin{array}{l}\text { The affected } \\
\text { immature fruits and } \\
\text { leaves }\end{array}$ \\
\hline
\end{tabular}




\subsection{Extraction of Bacteria from Primary Materials by Shaking in Buffer}

Samples were placed in a suitable container, such as a disposable $150 \mathrm{ml}$ plastic cup with lid or a $200 \mathrm{ml}$ Erlenmeyer flask. $30 \mathrm{ml}$ phosphate buffer or phosphate-buffered saline was added. The container was placed on a rotary shaker and then incubated at $200 \mathrm{rev} / \mathrm{min}$ for $1.0 \mathrm{~h}$. For samples with symptoms, an appropriate amount of macerate was selected for polymerase chain reaction (PCR) analysis. For asymptomatic samples extracted, suspension was concentrated by centrifugation. $50 \mathrm{ml}$ of Macerate was carefully poured either directly into the centrifuge tube, leaving the pulp in a container, or pre-filtered through filter paper and then centrifuged for 10 minutes, with an acceleration of $8000 \mathrm{~g}$, at $10^{\circ} \mathrm{C}$. The sample was also frozen at $-18^{\circ} \mathrm{C}$.

The supernatant was discarded without damage; the pellet was resuspended in $1 \mathrm{ml}$ of phosphate buffer and transferred to a sterile microtube. The extract was used immediately for the selection tests: biochemical and PCR analyses.

\subsection{Isolation of Pure Culture of Erwinia amylovora}

To isolate E. amylovora isolates from primary materials (diseased parts of plants), as well as to identify and store them in vitro, cultures commonly used for bacteria nutrient mediums: Meat-peptone agar (Meat extract (Difco)-3 g; Peptone (Difco)-5 g; Agar (Difco)-15 g; Water-1 liter; Soy-Tryptone agar (Tryptone (Difco)-15 g; Soy peptone-5 g; NaCl-5 g; Agar (Difco)-15 g; Distilled deionized water-1 L; pH-7.3) and and selective mediums were used, like Levan (Yeast extract-2 g; Bactopeptone-5 g; NaCl-5 g; Sucrose-50 g; Agar-20 g; Distilled water-1 liter; $\mathrm{pH}-7.0$ - 7.2), King's B medium (Peptone-20 g; glycerol-10 ml; $\mathrm{K}_{2} \mathrm{HPO}_{4}-1.5 \mathrm{~g}$; $\mathrm{MgSO}_{4} \cdot 7 \mathrm{H}_{2} \mathrm{O}-1.5 \mathrm{~g}$; Agar-15 - 20 g; Distilled water-1 liter, $\mathrm{pH}-7.0$ - 7.2).

A 30 - $50 \mu \mathrm{l}$ dose of plant extract suspension from diseased parts was added to the Petri dish and sequentially distributed over the surface of the medium on three plates with a spatula. The stroke method was also used for plating the plant extract suspension. For this purpose, four decimal dilutions of plant extract were prepared in the extraction buffer and then $50-100 \mu \mathrm{l}$ of undiluted extract, before each of the dilutions was plated on its medium with the stroke method. To control the quality of the medium, the reference strains of fire blight pathogen were plated.

\subsection{Enrichment in the Unripe Fruits}

Immature fruits are an ideal medium for bacterial blight pathogen, while constraining the growth of accompanying microorganisms. Therefore, enrichment on the biological material can be more efficient than media. For each sample, three to five immature fruits (or 1/4-1/2 of the fruit) of susceptible apple and/or pear varieties were used. One hundred $\mu$ of sample suspension was distributed between fruits by making a few nyxes through the fruit skin, to a depth of about $5 \mathrm{~mm}$, using disposable syringes with thin needles.

As a positive control, the same fruit varieties were inoculated with a pure culture suspension of blight pathogen at a concentration of $10^{6}$ cells $/ \mathrm{ml}$. 
As a negative control, the same fruit varieties were inoculated with a buffer in which a macerate was prepared. They were incubated in a humid chamber at $25^{\circ} \mathrm{C}$ to $27^{\circ} \mathrm{C}$ for five to seven days. Necrosis and white exudate were observed being produced by the fruits. With the development of typical symptoms, isolation and identification of a pure culture was performed.

\subsection{The Classical Biochemical Tests}

Biochemical tests were set for the study of phenotypic properties of isolates of fire blight.

\subsection{Molecular Identification}

\subsubsection{Sample Preparation of Samples for Tests Based on Polymerase Chain Reaction}

Levan-positive, non-fluorescent culture at a concentration of $10^{6} \mathrm{cells} / \mathrm{ml}$ in sterile distilled water suspension was prepared and used immediately or stored at $-18^{\circ} \mathrm{C}$ until PCR product was observed.

\subsubsection{Classic Analysis Based on the Polymerase Chain Reaction}

DNA isolation, restriction and agarose gel electrophoresis were carried out according to standard protocols. Amplification of $E$. amylovora gene $h r p N$ was performed with primers Eam1 (5'gaggaataccatatgagtctgaatacaagtg3') and Eam2 (5'agcgtcgaccagcttgccaagtgccat3'). Annealing temperature of primers was $52^{\circ} \mathrm{C}$.

\subsection{Sources of Antagonists}

Biocontrol antagonistic microorganisms (Streptomyces) from our laboratory collection were used in this study.

\subsection{In Vitro Determination of Antibiotic Activity of Antagonistic Microorganisms against Fire Blight Pathogen}

The N.S. Egorov [25] perpendicular stroke method was used. The antagonist culture was plated on the diameter of the Petri dishes; after four to five days, test cultures ( $E r$ winia amylovora) were plated. The agar blocks method was also used. Biocontrol antagonistic microorganisms (Streptomyces sp.) were plated onto the surface of the agar medium in a Petri dish, having formed during the growth of a continuous lawn. Cultures were incubated at a suitable temperature for four to five days. Then a sterile cork drill (6 - $8 \mathrm{~mm}$ in diameter) was used to cut from the layer agar blocks and transferred to the surface of the agar medium, inoculating only the test organism (Erwinia amylovora). Agar blocks were placed increasing (lawn) up at an equal distance from each other and from the edge of the cup tightly to the agar plate.

\subsubsection{Evaluation of Antagonistic Activity Biocontrol Agents in Liquid Media} Antagonistic activity of biocontrol agents against the bacterial blight pathogen was studied by co-cultivation of the antagonist and the test culture in a liquid medium. The Erwinia amylovora culture was incubated in $5 \mathrm{ml}$ tubes in a meat-peptone broth for 48 
hours. Then $1 \mathrm{ml}$ of an antagonist culture was added to each tube: Streptomyces bambargiensis SK-6.6; Streptomyces fumanus gn-2; Streptomyces Pr-3 and Streptomyces C1-4. After incubation at $28^{\circ} \mathrm{C}$ for 24 hours, tube contents were analysed and the activity of the biocontrol agents was evaluated.

\subsection{Screening the Antibiotic Activity of Antagonistic Microorganisms against the Bacterial Blight Pathogen on Apple and Pear Seedlings}

The potential of candidate antagonists to suppress the cell production of Erwinia amylovora on infected leaves was tested on susceptible local Aychurok apple seedlings and local Myskii pear seedlings. Seedlings were sprayed with suspensions of Erwinia amylovora $\left(1 \times 10^{6} \mathrm{ml}^{-1}\right)$ until runoff and placed in a moist chamber consisting of a plastic tray enclosed by a transparent plastic top. After two days of incubation at $15^{\circ} \mathrm{C}$ with diffuse light, the tops were removed from the trays and seedlings were further incubated for five days at $85 \% \mathrm{RH}, 15^{\circ} \mathrm{C}$ and with $16 \mathrm{hrs}$. light per day. Thereafter, E. amylovora-inoculated seedlings were sprayed with antagonist suspensions (containing $1 \times$ $10^{6}$ spores or cells ml-1) or water (containing $0.01 \%$ Tween 80 ) as controls. Two seedlings of both apples and pears were used for each replicate of each treatment. Contact between leaves of neighbouring plants was avoided.

Seedlings were grown for nine to 12 days at $15^{\circ} \mathrm{C}$, with $16 \mathrm{hrs}$ of light per day at 138 $\mu \mathrm{E} \mathrm{s}-1 \mathrm{~m}-2$. From both seedlings of each replicate, the youngest five true leaves were carefully removed, put into Duran bottles $(100 \mathrm{ml})$ containing $35 \mathrm{ml}$ of tap water with $0.01 \%$ Tween 80 . Four, 10,15 and 20 days after treatment with antagonist cultures, five leaves of the apple seedling were removed for microscopy and planting on the relevant mediums. Pathogen colonies were counted on each single leaf and the average number of colonies forming units was calculated.

\subsection{Screening the Chemical Bactericide against Bacterial Blight Pathogen on Apple and Pear Seedlings}

Two seedlings of apple and pears with clear symptoms of fire blight after the application of Erwinia amylovora were sprayed with commercial chemical product Roder 80 WP until runoff and seedlings were incubated for five days at $85 \% \mathrm{RH}, 15^{\circ} \mathrm{C}$ and given $16 \mathrm{hrs}$. of light per day. The seedlings sprayed by water were used as control.

\subsection{Statistical Analysis}

Data were analysed following the GLIM program of the Royal Society of London [26]. Significant differences between the two mean values, due to different treatments or varieties and their interaction at a crop growth stage, were computed by comparing their significant levels at $\mathrm{P}<0.05$.

\section{Results and Discussion}

\subsection{Phenotypic Characterization}

Erwinia amylovora species were isolated from exudates of diseased apple blossoms (Chy 
region, botanical garden), from infected pear fruit (Chy region, botanical garden; Osh region, private orchards) and from bent branches of hawthorn (Jalal Abad region, wild nut forest). With direct isolation, a pathogen from the diseased plant samples, with a round shape and oily white-yellow colonies with smooth edges, was grown on meat-peptone. On the King's B medium, the colonies, unlike that of the Pseudomonas (which stained the medium green) caused no staining. This is an important diagnostic sign, confirming that the isolated cultures were Erwinia amylovora. The most characteristic diagnostic feature of these bacteria is the formation of white, fatty, winding edges and raised colonies on a Levan medium. All selected strains were gram-negative and showed positive catalase activity with gelatine liquefying within 24 days, indicating the presence of protease enzymes; also, they did not reduce nitrates (Table 2).

\subsection{PCR Analysis}

Specific primers were used, Eam1 (agcgtcgaccagcttgccaagtgccat) and Eam2 (agcgtcgaccagcttgccaagtgcca), to identify the chromosomal gene hrpN. This gene encodes a protein, Harpin, described in the literature as a component of the secretion of the third type and the major virulence factor E. amylovora [27]. 16Sr RNA genes of the bacteria Erwinia amylovora were identified using common primers: $27 \mathrm{fr}$ and $1427 \mathrm{fr}$ (Figure $2(a))$ and the genes responsible for the pathogenicity were identified using the primers Eam1 and Eam2. The hrpN gene was amplified from E. amylovora strains from the Chy and Osh regions (Figure $2(\mathrm{~b})$ ).

Table 2. Confirmed nutritional and enzymatic tests.

\begin{tabular}{|c|c|}
\hline Test name & Results \\
\hline Gram stain & - \\
\hline Formation of Levan & + \\
\hline $\begin{array}{l}\text { The fluorescent pigment on King's medium B } \\
\text { (under ultraviolet light) }\end{array}$ & - \\
\hline Oxidative/Fermentation $(\mathrm{O} / \mathrm{F})$ test & $\mathrm{O}+/ \mathrm{F}+$ \\
\hline Catalase & + \\
\hline Test Kovach on oxidase & - \\
\hline Nitrate reduction & - \\
\hline Utilization of citrate & + \\
\hline Growth at $39^{\circ} \mathrm{C}$ & - \\
\hline Colliquation of gelatine & + \\
\hline Urease & - \\
\hline Indole & - \\
\hline The reduction of sucrose derivatives & + \\
\hline
\end{tabular}




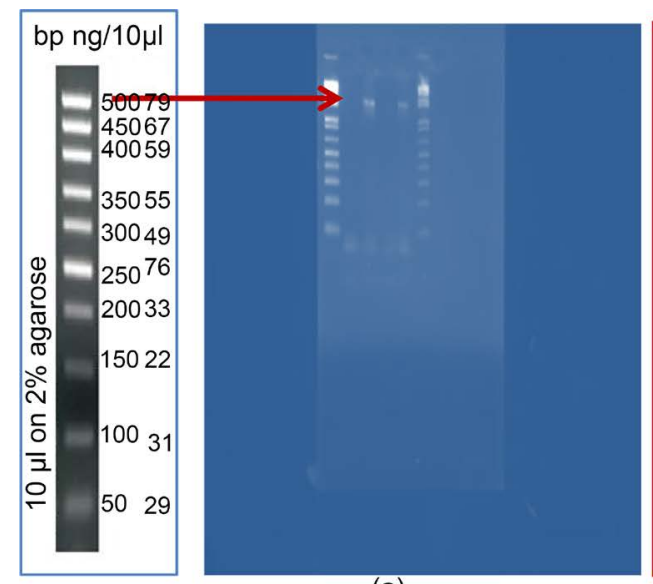

(a)

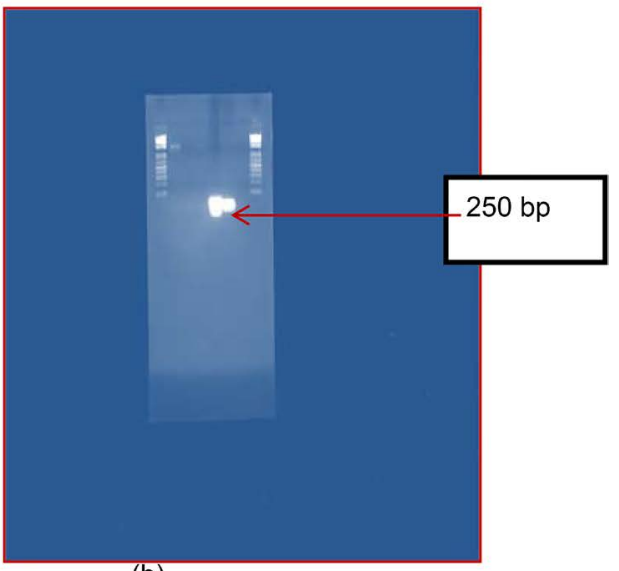

(b)

Figure 2. (a) electrophoretic profile of $16 \mathrm{Sr}$ RNA of Erwinia amylovora bacteria and (b) PCR products obtained after amplification with Eam1 and Eam2 primers for hrpN gene from bent branches of hawthorn and exudate of apple flowers.

\subsection{Pathogenicity}

In vitro bioassay to identify the hypersensitivity of non-specific plant organisms to isolated fire blight pathogen isolates was performed. A room geranium (Pelargonium zonala) was used, which is not a host for the pathogen. When $0,1 \mu \mathrm{l}\left(1 \times 10^{7} \mathrm{cells} / \mathrm{ml}\right)$ suspension of Erwinia amylovora was injected into the space between the leaves veining the necrotic spots on the leaves appeared after 48 hours. This indicates that these isolates have aggressive phytopathogenic properties and have a set of active enzymes decomposing vegetable cells and tissues (Figure 3). Enzyme-metabolites produced by these bacteria cause hypersensitivity on the part of the plant organism, which is evident in the form of necrotic spots.

As a second non-specific plant organism, beans (Phaseolus vulgarilus) were used, grown in an indoor environment. With the injection of the Erwinia amylovora culture suspension in a dose of $0,1 \mu \mathrm{l}\left(1 \times 10^{7}\right.$ cells $\left./ \mathrm{ml}\right)$ the necrotic spots appeared after seven days on the leaf of this plant, evidence that bean cells and tissues have a hypersensitivity to the pathogen, although it emerged later here than in the geranium.

Another of the main methods of diagnosis is a test for pathogenicity, which was tested on immature pear fruit. The bacterial suspension was applied to a fruit damaged by a pin and incubated for two days in a humid chamber. A pear fruit served as the control, pierced with a pin, but instead of Erwinia amylovora, a suspension of sterile water was applied. The test was positive, as the infected pear displayed a milky white exudate (Figure 4).

\subsection{Determination of Antagonistic Effects of Streptomyces against Erwinia amylovora}

Currently, protective measures against the fire blight pathogen are reduced to mechanical methods, cutting the damaged parts and sometimes the entire tree. There is still no effective chemical and biological plant protection. Finding and screening bio- 
logical agents effective against the bacterial blight pathogen among bioactive compounds which produce microorganisms is an important problem in plant protection.

In the laboratory of the Plant Protection Department of Kyrgyz Turkish Manas University, there is a working collection of actinomycetes, bacteria and fungi that produce different metabolites and bioactive compounds. For example, only actinomycetes are produced, about 17,000 secondary metabolites. They include substances with antagonistic properties against harmful bacteria and fungi, while also providing material with a bio-stimulating effect on seeds and seedlings of agricultural plants [28]-[30].

Thus, actinomycetes are promising agents in protecting plants against phytopathogens and in preserving and increasing the harvest. Among prokaryotes, the representatives of the Streptomyces genus are very important, as almost all commercially produced antibiotics are obtained from these microorganisms (Table 3).

The results obtained when using the touch method of the nutrient medium surface are shown in Table 4.
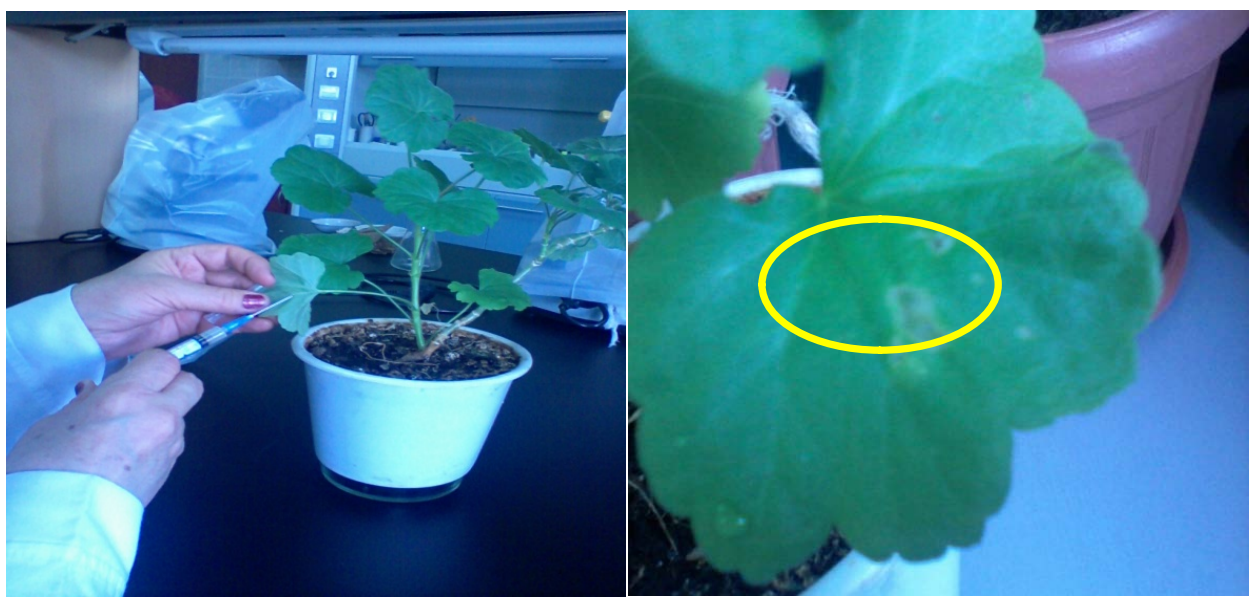

Figure 3. Bioassay on pathogenicity of Erwinia amylovora (Burrill) to non-host plants (Pelargonium zonala) in laboratory conditions.

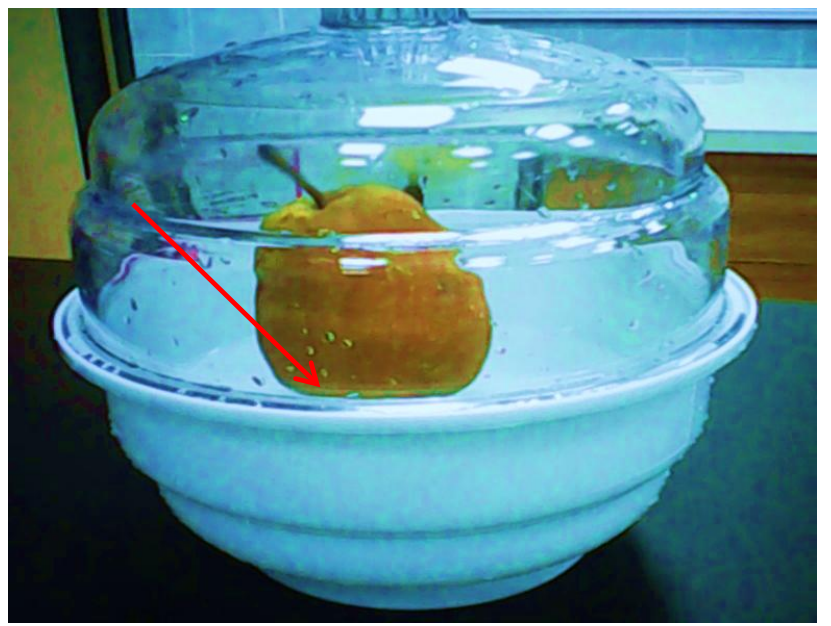

Figure 4. The appearance of milky white exudate on infected immature pear fruit. 
Table 3. The origin and cultural features of Streptomyces strains used in this study.

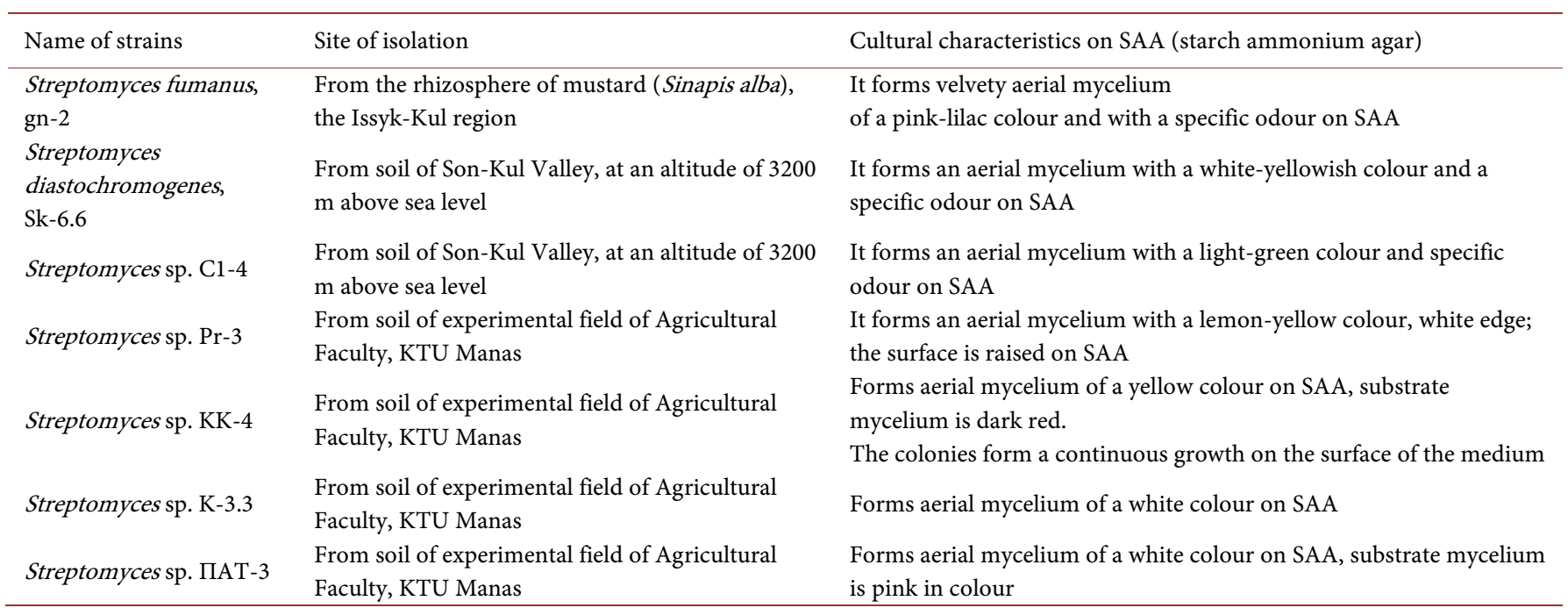

Table 4. Antagonistic activity against bacterial blight pathogen in laboratory experiments.

\begin{tabular}{|c|c|c|c|c|c|c|}
\hline \multicolumn{7}{|c|}{ Antagonistic activity of the microorganisms after seven days } \\
\hline $\begin{array}{c}\text { Test } \\
\text { culture }\end{array}$ & $\begin{array}{c}\text { Streptomyces } \\
\text { bambergiensis SK-6.6 }\end{array}$ & $\begin{array}{c}\text { Streptomyces } \\
\text { diastochromogenes } \\
\text { SK- } 2.2\end{array}$ & $\begin{array}{l}\text { Streptomyces } \\
\text { sp. KK-4 }\end{array}$ & $\begin{array}{l}\text { Streptomyces sp. } \\
\text { C1-4 }\end{array}$ & $\begin{array}{c}\text { Streptomyces sp. } \\
\text { K-3.3 }\end{array}$ & $\begin{array}{l}\text { Streptomyces sp. } \\
\text { Pr-3 }\end{array}$ \\
\hline $\begin{array}{l}\text { Erwinia } \\
\text { amylovora }\end{array}$ & $\begin{array}{l}\text { Inhibits growth of } \\
\text { pathogen }\end{array}$ & $\begin{array}{c}\text { Inhibits growth of } \\
\text { pathogen }\end{array}$ & $\begin{array}{l}\text { Shows no } \\
\text { activity }\end{array}$ & Hyperparasitism & Shows no activity & Hyperparasitism \\
\hline
\end{tabular}

As the results of the research have shown, the antagonistic activities of different biocontrol strains were different. The strain Streptomyces bambargiensis $S K-6.6$ showed a strong antagonistic effect on Erwinia amylovora, providing complete inhibition of the growth and development of the colonies of this phytopathogen. Another strain, Streptomyces diastochromogenes $S K-2.2$ inhibited the development of phytopathogens, causing weakness and oppression of its colonies. At the same time, other biocontrol agents such as Streptomyces sp. C1-4 and Streptomyces sp. Pr-3 showed a hyper-parasitic effect, using the colonies of Erwinia amylovora as a source of nutrients, growing on the cells of pathogens (Figure 5). Other antagonistic microorganisms, such as Streptomyces sp. KK-4 and Streptomyces sp. K-3.3 have showed no antagonistic effects against Erwinia amylovora.

\subsection{Evaluation of Antagonistic Activity of Biocontrol Agents in Liquid Media}

Antagonistic activity of biocontrol agents against the bacterial blight pathogen was studied by co-cultivation of the antagonist and the test culture in a liquid medium. The Erwinia amylovora culture was incubated in $5 \mathrm{ml}$ tubes in a meat-peptone broth for 48 hours. Then, $1 \mathrm{ml}$ of the antagonist culture was added to each tube: Streptomyces bambargiensis SK-6, 6; Streptomyces fumanus gn-2, Streptomyces sp. C-4; Streptomyces sp. Pr-3. After incubation at $28^{\circ} \mathrm{C}$ for 24 hours, the tube contents were studied through 
microscopy and the activity of the biocontrol agents was evaluated.

In the liquid medium, Streptomyces $S K-6,6$ bambargiensis strain showed a high activity against Erwinia amylovora. Phytopathogen cells were completely lysed by the enzymes of the antagonist; in the micro pictures only mycelia and hyphae of Streptomyces (purple arrows) were visible and there were no phytopathogens cells (Figure 6(a)). The Streptomyces fumanus gn-2 strain's activity was weak, as phytopathogen cells multiplied rapidly in the presence of antagonists (blue arrows) (Figure 6(b)).

The strain Streptomyces sp. $K-4$ also showed an active effect on phytopathogen cells when co-cultured together. A complete lysis of Erwinia amylovora cells with an

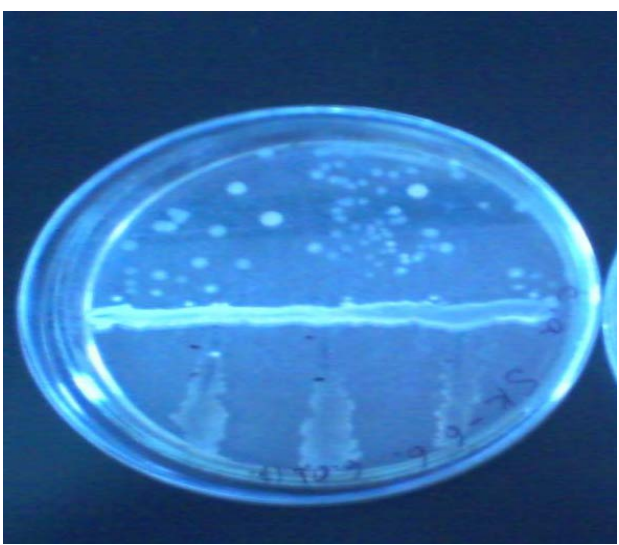

(a)

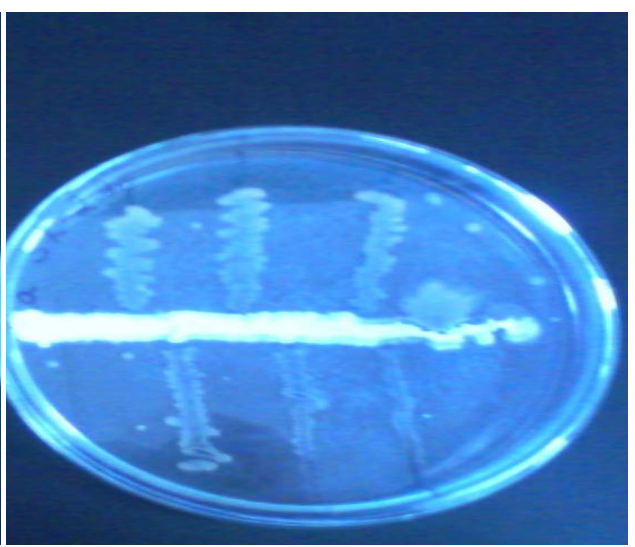

(b)

Figure 5. (a) Antagonistic effect of the Streptomyces bambargiensis SK-6.6 strain against Erwinia amylavora; (b) antagonistic effect of the Streptomyces diastochromogenes $S K-2.2$ strain against Erwinia amylovora.

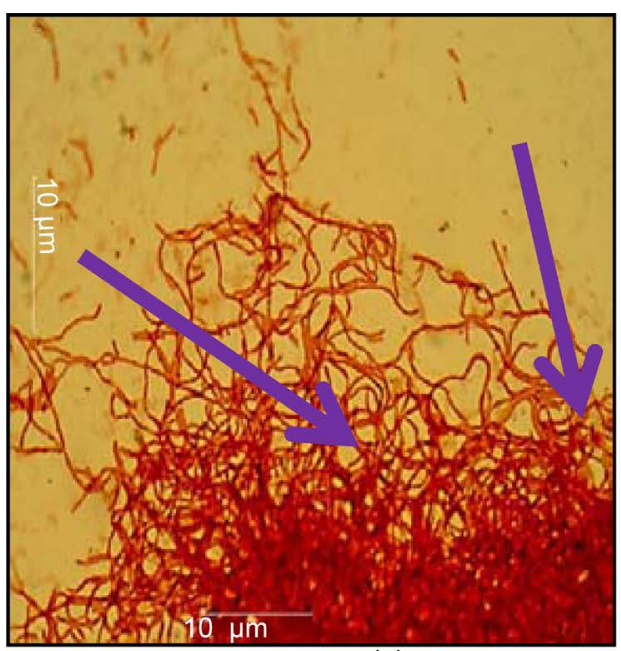

(a)

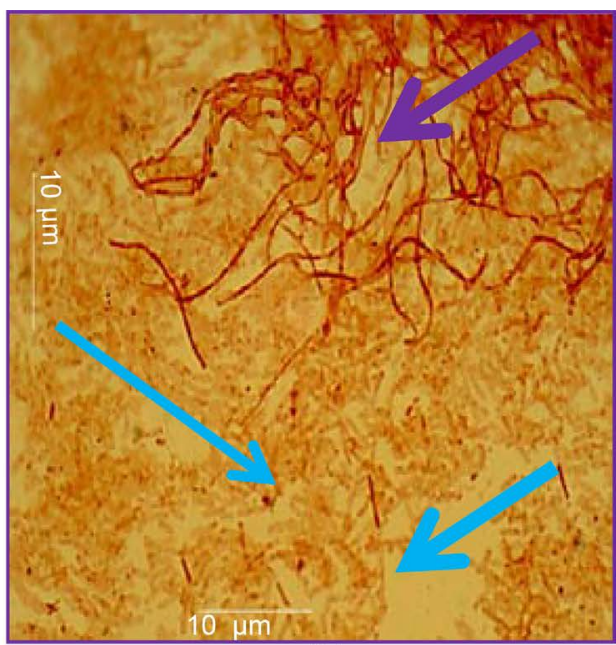

(b)

Figure 6. (a) where in a liquid medium Streptomyces bambargiensis SK-6.6 (1 ml) + Erwinia amylovora $(5 \mathrm{ml})$ were co-cultured, purple arrows indicate the mycelium and hyphae of Streptomyces bambargiensis SK-6.6; (b) where in a liquid medium Streptomyces fumanus gn-2 (1 ml) + Erwinia amylovora $(5 \mathrm{ml})$ were co-cultured, blue arrows indicate the developing cells of Erwinia amylovora, in $48 \mathrm{~h}$ after the incubation. 
antagonistic effect of Streptomyces sp. K-4 was observed. Streptomyces sp. Pr-3 did not show an antagonistic effect to the pathogen; on the other hand, Erwinia amylovora cells rapidly multiplied (Figure $7(\mathrm{a})$ ). The other biocontrol organism, Streptomyces $s p$. C1-4, showed a sustained strong antagonistic activity against phytopathogens when they co-cultured together. Unlike other strains of the genus Streptomyces, this strain has noticeable sporulation and formed spores in chains as a short irregular helix. In this case, there was a complete absence of Erwinia amylovora cells (Figure 7(b)).

\subsection{Screening Seedlings}

Seven days after artificial infestation of the highly susceptible local Aychurok variety of apple seedlings and the Mayskiy variety of pear seedlings, the first signs of the disease's symptoms emerged: the leaf first appeared water-soaked, they next turned dark green, then wilted and finally turned brownish to black (Figure 8). Five leaves from each tree were stripped and placed in $100 \mathrm{ml}$ of sterile water; after shaking for one hour in $1 \mathrm{ml}$ of suspension, they were planted on the nutrient media. Pathogen colonies were counted on a single leaf and the average number of colonies was calculated. Direct microscopy $(1000 \times)$ of diseased leaves and the colonies growing on the medium found cells of the pathogen (Figure 9).

The dynamics of $E$. amylovora cell development on the surface of artificially infected leaves was monitored during the 18 days. The number of colony forming units (CFU) of the pathogen on the medium was determined and the results show that the number of bacterial CFU increased daily. If on a single pear's leaf the amount of bacterial CFU after four days was 12 , after 10 days it was 28 , while after 18 days it reached 48 . On a single apple's leaf the average of bacterial CFU after four days was between one and three, after 10 days it was five and after 18 days it reached 11 . This indicates that the pear leaves were more sensitive to the effects of the pathogen than the apple leaves; in

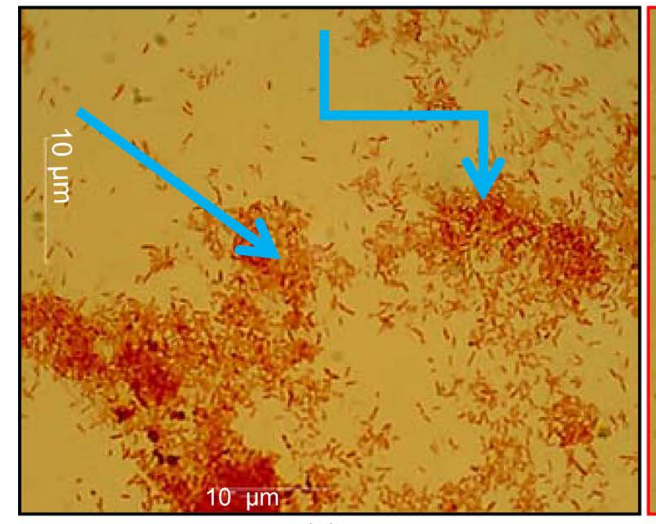

(a)

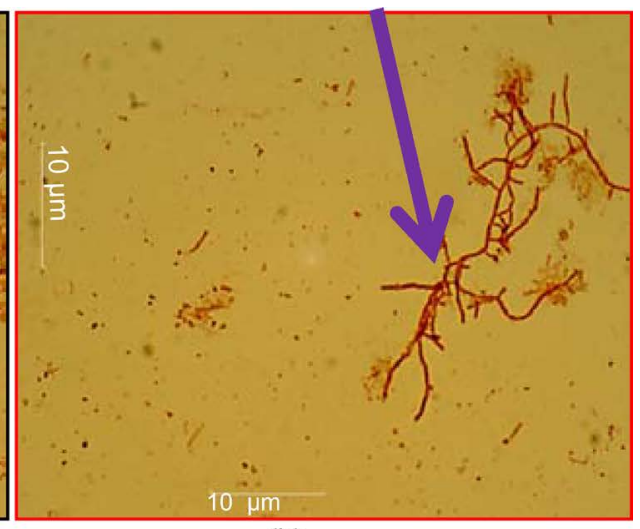

(b)

Figure 7. (a) where Streptomyces sp. Pr-3 $(1 \mathrm{ml})+$ Erwinia amylovora $(5 \mathrm{ml})$ were co-cultured in a liquid medium, blue arrows indicate the developing cells of Erwinia amylovora; (b) where Streptomyces sp. Cl-4 (1 ml) + Erwinia amylovora $(5 \mathrm{ml})$ were co-cultured in the liquid medium, purple arrows indicate the mycelium and hyphae of Streptomyces sp. C1-4; in $48 \mathrm{~h}$ after the incubation. 


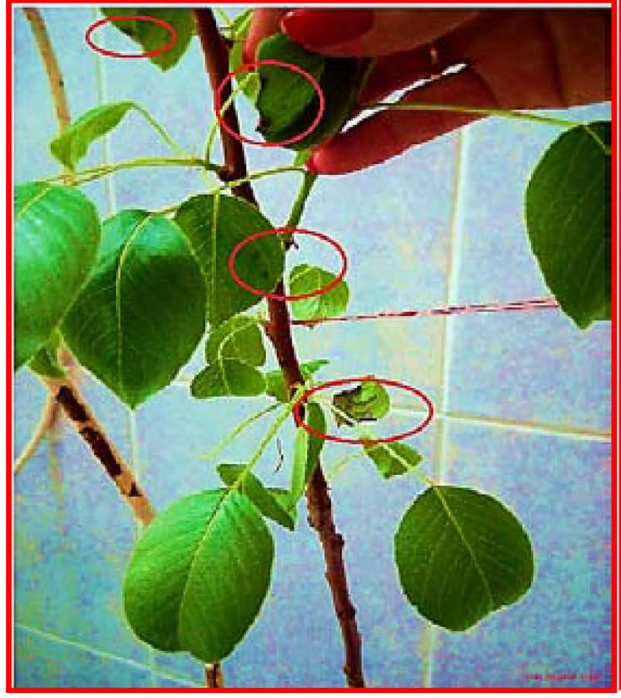

(a)

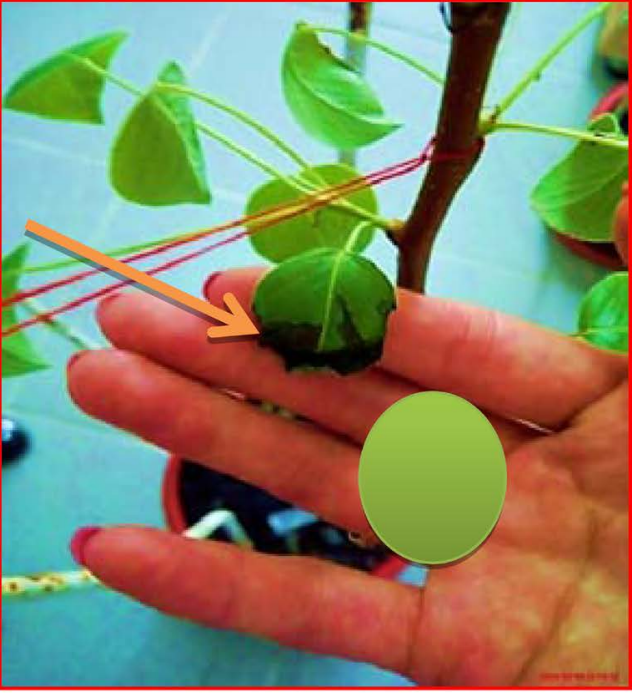

(b)

Figure 8. (a) The pear and (b) the apple seedlings with diseased symptoms on the leaves after spraying with $E$. amylovora $\left(1 \times 10^{6} \mathrm{ml}^{-1}\right)$ after seven days.

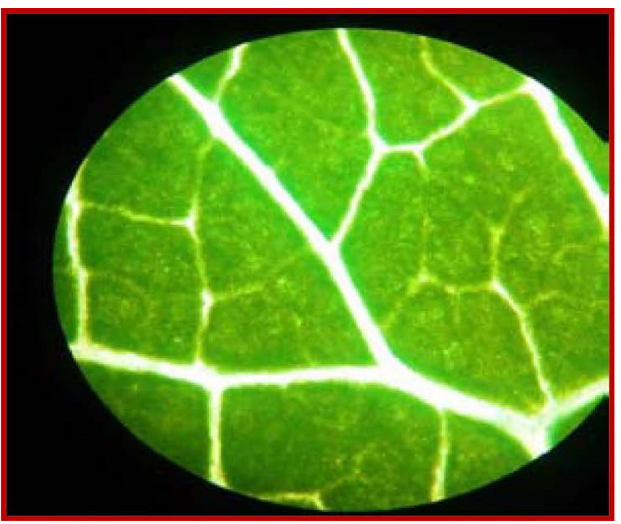

(a)

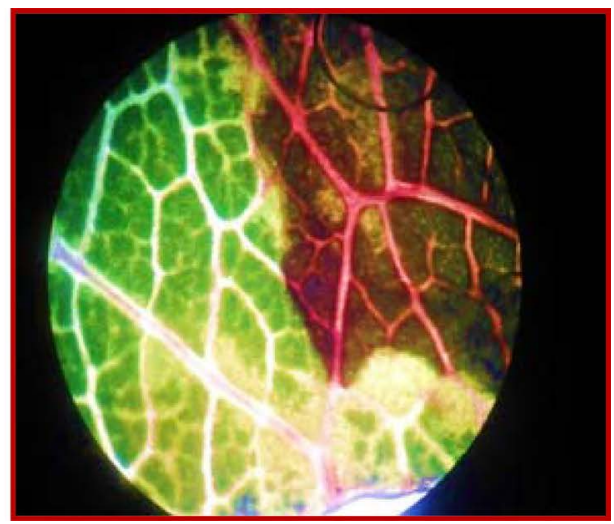

(b)

Figure 9. The picture under the microscope: (a) healthy leaf tissue and (b) diseased leaf tissue with the signs of fire blight.

reality, pear leaves were subjected to more severe damage and the number of damaged leaves was larger than in the apple (Table 5).

Within 10 days of artificial infection with E. amylovora, the number of healthy leaves decreased significantly; the percentage of damaged apple leaves was $28.0 \%-29.2 \%$, while pear leaves were at $55 \%-56 \%$. In the control group, the percentage of damaged leaves increased from $46 \%$ to $52 \%$ (Figure 10 ).

Ten days after infection, the seedlings' leaves were treated with Streptomyces C1-4 at a dose of $10^{6}$ spores $/ \mathrm{ml}$. A second treatment with the antagonist product was conducted seven days after the first treatment, using the same dose.

15 days after two applications of the antagonist product with a dose of $10^{6} \mathrm{spores} / \mathrm{ml}$, the number of recovered leaves has increased; the number of apple healthy leaves 
reached $22 \pm 0.03$; pear healthy leaves, $38 \pm 0.02$ (Figure 11).

Table 5. Dynamics of E. amylovora CFU grown on the surface of the medium after artificial infection.

\begin{tabular}{|c|c|c|c|c|}
\hline $\begin{array}{l}\text { Options for } \\
\text { experiments }\end{array}$ & $\begin{array}{c}\text { Four days } \\
\text { after infection }\end{array}$ & $\begin{array}{c}10 \text { days } \\
\text { after infection }\end{array}$ & $\begin{array}{c}15 \text { days } \\
\text { after infection }\end{array}$ & $\begin{array}{c}18 \text { days } \\
\text { after infection }\end{array}$ \\
\hline \multicolumn{5}{|l|}{ Pear seedlings } \\
\hline 1 & $12 \pm 0.01$ & $23 \pm 0.041$ & $26 \pm 0.02$ & $28 \pm 0.03$ \\
\hline 2 & $12 \pm 0.01$ & $36 \pm 0.037$ & $39 \pm 0.036$ & $42 \pm 0.04$ \\
\hline \multicolumn{5}{|l|}{ Apple seedlings } \\
\hline 2 & $1 \pm 0.01$ & $3 \pm 0.01$ & $5 \pm 0.02$ & $5 \pm 0.02$ \\
\hline 3 & - & $1 \pm 0.01$ & $4 \pm 0.02$ & $6 \pm 0.01$ \\
\hline Control & $8 \pm 0.03$ & $15 \pm 0.02$ & $21 \pm 0.03$ & $37 \pm 0.04$ \\
\hline
\end{tabular}

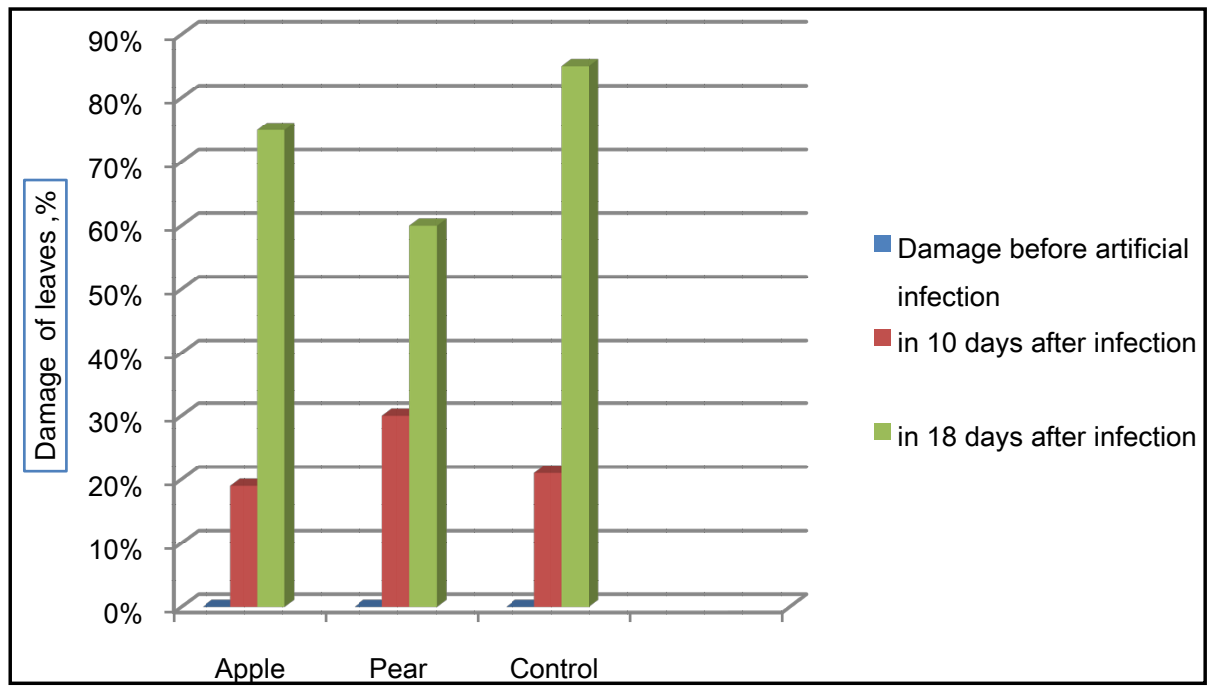

Figure 10. Damage level of seedling leaves after infection by Erwinia amylovora.

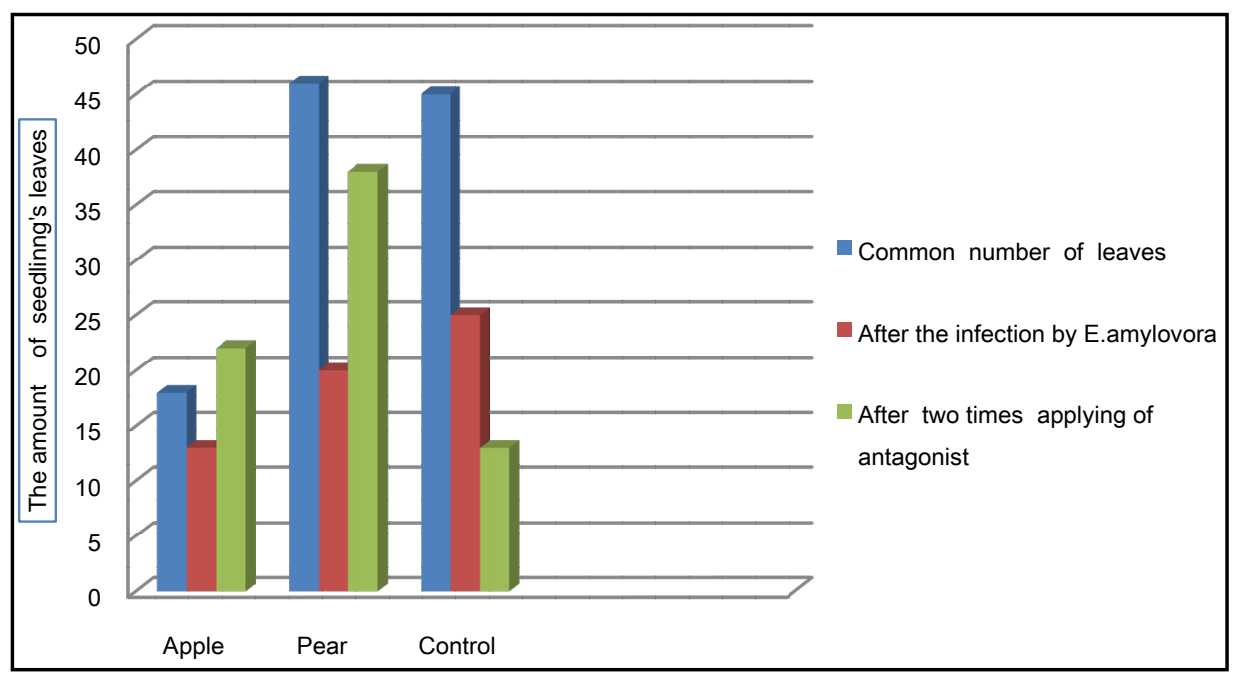

Figure 11. The amount of seedling's leaves before and after the infection and application of the antagonist. 
During the same time, the number of damaged apple leaves decreased by $41 \%$, damaged pear leaves by $35 \%$, whereas in the control for seedlings, the disease evolved and reached $95 \%$ (Figure 12).

The progression of the disease caused by Erwinia amylovora was arrested. 15 days after two treatments with Streptomyces sp. C1-4, the number of infected leaves had not increased and progression of the disease had completely stopped.

To determine the shelf life of the antagonist's spores on the leaf surfaces of seedlings after treatment, the treated leaves of seedlings were removed and located on the surface of the culture media with outer and inner surfaces. The leaves treated with Streptomyces sp. C1-4 were planted on an ammonium starch medium (for actinomycetes) (Figure 13).

The intensity and density of the antagonist's colonies growing around the leaves on

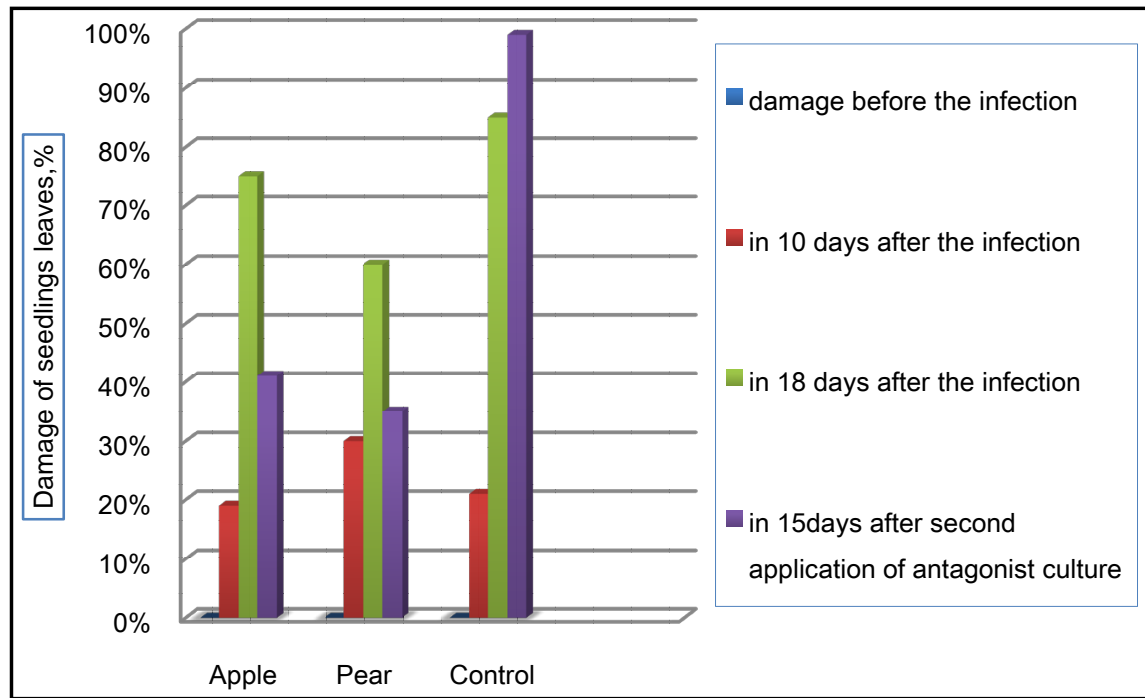

Figure 12. Reduced damage of apple and pear leaves after two sprayings of the antagonist culture.

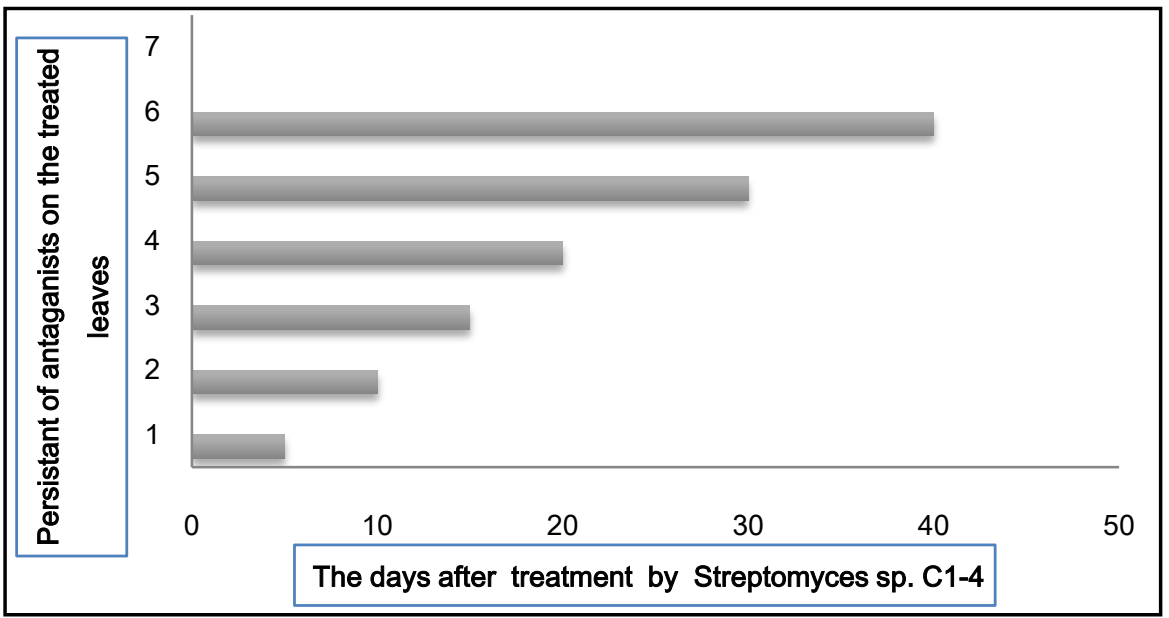

Figure 13. The shelf life of Streptomyces sp. C1-4 antagonist's spores on leaf surfaces of seedlings, 40 days after the second treatment. 
this medium have proven persistent on the leaf surface after treatment. The longer they remain on the surface of diseased leaves, the greater the probability that they will suppress the development of the pathogen.

The results shown for the colonies of Streptomyces sp. C1-4 were obtained 10 - 40 days after the second treatment, showing intensive growth around the leaves planted on this medium (Figure 14). This suggests that the Streptomyces sp. C1-4 has a double effect: as an antagonist and as a hyper-parasite, which could suppress the development of pathogen cells on diseased leaves and use them as a nutrient source, by producing enzymes that degrade the cell walls of pathogen cells.

Testing the chemical bactericide against fire blight. In recent years, Roder $80 \mathrm{WP}$ chemical bactericide has been used successfully against fire blight. This product has a systemic effect at a dose of $400 \mathrm{~g} / 100 \mathrm{~L}$ water. In a short time, it suppresses the progression of the disease and is distributed to all of a plant's organs. During the growing season, this product can be applied three to four times: before bud formation and flowering, and twice after flowering, with an interval of seven to 10 days.

In this study, diseased apple and pear seedlings infected with the pathogen were sprayed with this chemical preparation in a dose of 100 grams per $25 \mathrm{~L}$ water. Three days after spraying, the disease progression had been suspended.

Burnt and damaged edges of the leaves had not widened and leaves with injuries remained on the branches; new lesions did not develop. The active ingredient of this chemical is fosetyl-al at $80 \%$, which, in the short term, stops the development of fire blight. However, the leaves with uninfected parts became rigid. These leaves did not fall from the branches, preventing the emergence of new leaves. When a biological product based on Streptomyces sp. C1-4 was used, the sick parts dried up and the uninfected parts were preserved in their natural state; the leaf tissue did not become rigid, as with a chemical drug. Thus, the biological antagonist affects only the pathogen and has no adverse effect on leaf tissue. This means that by stopping the progression of the disease, a diseased plant's tissue can begin to recover and function normally (Figure 15). In the
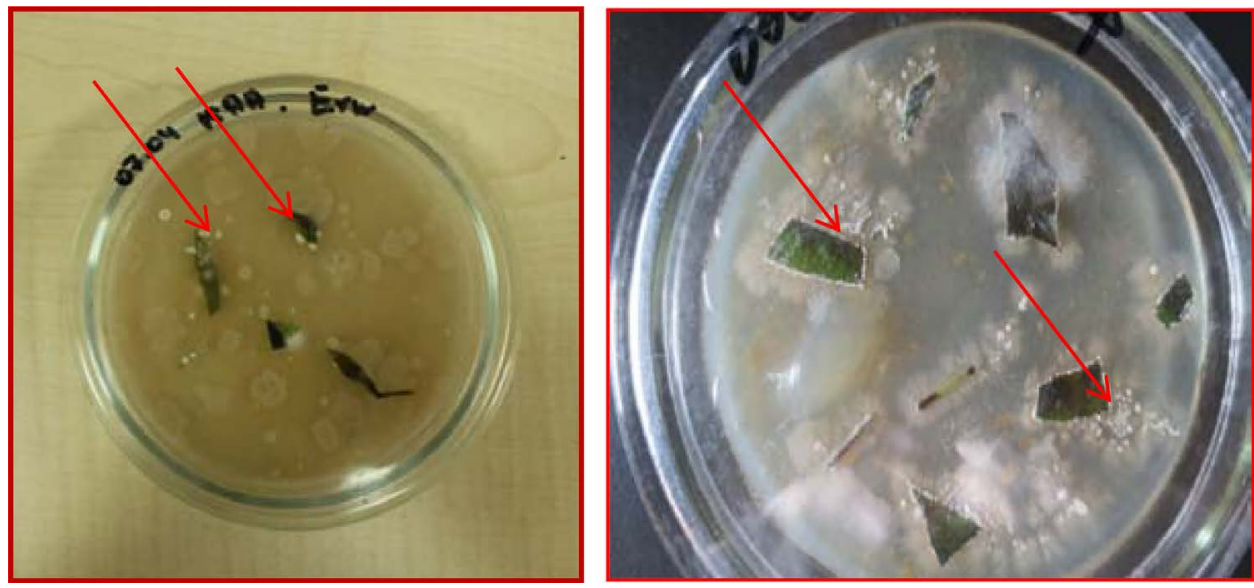

Figure 14. The leaf pieces taken from seedlings are shown by red arrows, overgrown by colonies of Streptomyces sp. C1-4 on this medium. 


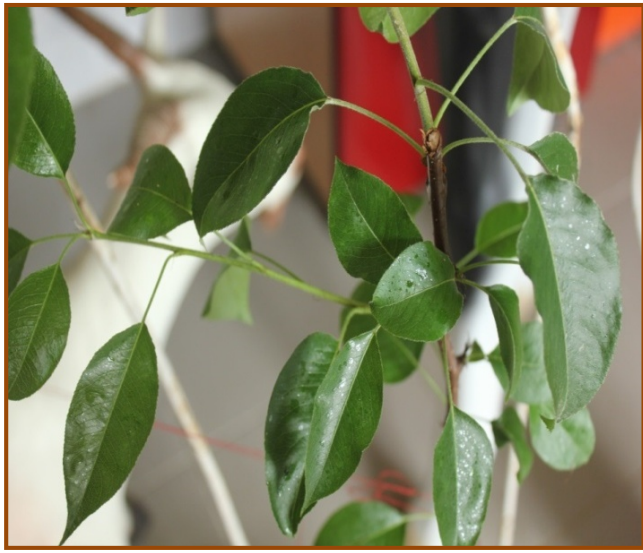

(a)

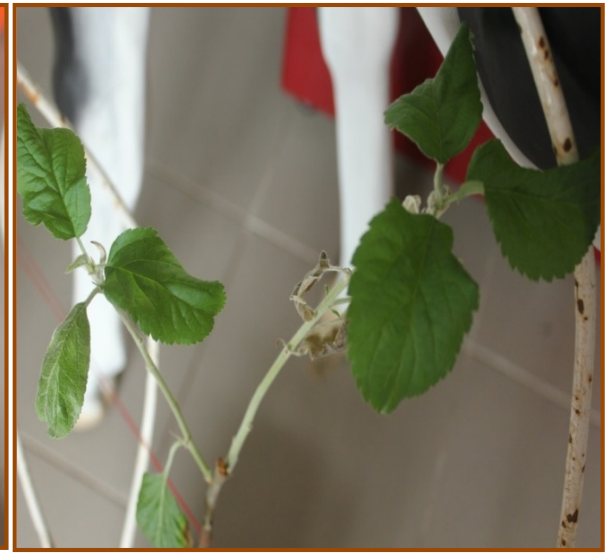

(b)

Figure 15. (a) Recovering leaves of pear seedlings and (b) recovering leaves of apple seedlings 40 days after second treatment.

application of the chemical equivalent, it affects not only the pathogen but the plant itself, meaning that diseased and healthy tissues become unviable. To restore the whole plant, there is a need for an additional mitigating safety procedure to protect against the chemical's affects.

\section{Conclusions}

E. amylovora as an economically important pathogen remains largely unexplored and/or is far from properly understood in Kyrgyzstan. A lot is still unknown about the biology, host range and ecological behaviour of these bacteria on their host plants in the different ecosystems of the country.

The present work is one of the first devoted to the study of the spread of fire blight in Kyrgyzstan. Local pure cultures of Erwinia amylovora, isolated from diseased organs of Rosaceae plants, were tested for pathogenicity on apple and pear seedlings. They showed an aggressive pathogenicity to seedlings for seven days after artificial infection. The Streptomyces strain C1-4 was selected after several in vitro tests as an effective antagonist and hyper-parasitic agent to Erwinia amylovora for spraying the diseased leaves of apple and pear seedlings. Streptomyces $C 1-4$ has shown a significant effect against Erwinia amylovora after two applications. A suitable time for this bioproduct's application is spring, when the symptoms of fire blight start to develop on the leaves of trees and the air temperature is $18^{\circ} \mathrm{C}-23^{\circ} \mathrm{C}$.

Spraying with Streptomyces product should be repeated three times, with an interval of 10 days, to completely suppress the infection. In contrast to the chemical preparation, a biological product based on Streptomyces $C 1-4$ has a bactericidal effect only on the pathogen, with no adverse effects to the plant itself; it also contributes to recovery and the emergence of new leaves, to aid the complete recovery of the whole plant. Persistence of spore antagonists on leaf surfaces lasted up to 40 days after the two sprays. It is necessary to apply one additional treatment of the biological product, through which it is possible to achieve a final, full recovery for trees from this disease. 


\section{References}

[1] Rosselo, M., Pefialver, J., Llop, P., Gorris, M.T., Chartier, R., Garcia, F., Monton, C., Cambra, M. and Lopez, M.M. (2006) Identification of an Erwinia sp. from Different Erwinia amylovora and Responsible for Necrosis on Pear Blossoms. Canadian Journal of Plant Pathology, 28, 30-41. http://dx.doi.org/10.1080/07060660609507268

[2] Vrancken, K., Holtappels, M., Schoofs, H., Deckers, T. and Valcke, R. (2013) Pathogenicity and Infection Strategies of the Fire Blight Pathogen Erwinia amylovora in Rosaceae: State of the Art. Microbiology, 159, 823-832. http://dx.doi.org/10.1099/mic.0.064881-0

[3] Brulez, W. and Zeller, W. (1981) Seasonal Changes of Epiphytic Erwinia amylovora on Ornamentals in Relation to Weather Conditions and Course of Infections. Acta Horticulturae, 117, 37-43. http://dx.doi.org/10.17660/ActaHortic.1981.117.5

[4] Miller, T.D. and Schroth, M.N. (1972) Monitoring the Epiphytic Population of Erwinia amylovora on Pear with a Selective Medium. Phytopathology, 62, 1175-1182. http://dx.doi.org/10.1094/Phyto-62-1175

[5] Bereswill, S., Bugert, P., Ller, I.B. and Geider, K. (1995) Identification of the Fire Blight Pathogen, Erwinia amylovora, by PCR Assays with Chromosomal DNA. Applied and Environmental Microbiology, 61, 2636-2642.

[6] Maes, M., Orye, K., Bobev, S., Devreese, B., Van Beeumen, J., De Bruyn, A., Busson, R., Herdewijn, P., Morreel, K. and Messens, E. (2001) Influence of Amylovoran Production on Virulence of Erwinia amylovora and a Different Amylovoran Structure in E. amylovora Isolates from Rubus. European Journal of Plant Pathology, 107, 839-844. http://dx.doi.org/10.1023/A:1012215201253

[7] Nimtz, M., Mort, A., Domke, T., Wray, V., Zhang, Y., Qiu, F., Coplin, D. and Geider, K. (1996) Structure of Amylovoran, the Capsular Exopolysaccharide from the Fire Blight Pathogen Erwinia amylovora. Carbohydrate Research, 287, 59-76. http://dx.doi.org/10.1016/0008-6215(96)00070-5

[8] Bellemann, P. and Geider, K. (1992) Localization of Transposon Insertions in Pathogenicity Mutants of Erwinia amylovora and Their Biochemical Characterization. Journal of General Microbiology, 138, 931-940. http://dx.doi.org/10.1099/00221287-138-5-931

[9] Geier, G. and Geider, K. (1993) Characterization and Influence on Virulence of the Levansucrase Gene from the Fireblight Pathogen Erwinia amylovora. Physiological and Molecular Plant Pathology, 42, 387-404. http://dx.doi.org/10.1006/pmpp.1993.1029

[10] Koczan, J.M., Lenneman, B.R., McGrath, M.J. and Sundin, G.W. (2011) Cell Surface Attachment Structures Contribute to Biofilm Formation and Xylem Colonization by Erwinia amylovora. Applied and Environmental Microbiology, 77, 7031-7039.

http://dx.doi.org/10.1128/AEM.05138-11

[11] Koczan, J.M., McGrath, M.J., Zhao, Y. and Sundin, G.W. (2009) Contribution of Erwinia amylovora Exopolysaccharides Amylovoran and Levan to Biofilm Formation: Implications in Pathogenicity. Phytopathology, 99, 1237-1244.

http://dx.doi.org/10.1094/PHYTO-99-11-1237

[12] Oh, C.S. and Beer, S.V. (2005) Molecular Genetics of Erwinia amylovora Involved in the Development of Fire Blight. FEMS Microbiology Letters, 253, 185-192. http://dx.doi.org/10.1016/j.femsle.2005.09.051

[13] Schroth, M.N., Thomson, S.V., Hildebrand, D.C. and Moller, W.J. (1974) Epidemiology and Control of Fire Blight. Annual Review of Phytopathology, 12, 389-412. http://dx.doi.org/10.1146/annurev.py.12.090174.002133

[14] Paulin, J.P. and Lachaud, G. (1984) Comparison of the Efficiency of Some Chemicals in 
Preventing Fire Blight Blossom Infections. Acta Horticulturae, 151, 209-214. http://dx.doi.org/10.17660/ActaHortic.1984.151.27

[15] Raafat, K.H., Hanan, S.A. and Rabab, A.M. (2015) Antibacterial Activity of Antagonistic Bacteria and Plant Extract on Erwinia amylovora the Pathogen of Fire Blight Disease in Egypt. International Journal of Phytopathology, 4, 73-79.

[16] Özaktan, H. and Bora, T. (2004) Biological Control of Fire Blight in Pear Orchards with a Formulation of Pantoea agglomerans Strain Eh 24. Brazilian Journal of Microbiology, 35, 224-229. http://dx.doi.org/10.1590/S1517-83822004000200010

[17] Kearns, L. (1993) Biological Control of Erwinia amylovora by Erwinia herbicola. Doctora Theses. http://library.canterbury.ac.nz/thesis/etheses_copyright.shtml

[18] Johnson K.B. and Stockwell V.O. (1998) Management of Fire Blight: A Case Study in Microbial Ecology. Annual Review of Phytopathology, 36, 227-248. http://dx.doi.org/10.1146/annurev.phyto.36.1.227

[19] Nuclo, R., Johnson, K.B., Sugar, D. and Stockwell, V.O. (1996) Importance of Secondary Spread of Bacterial Antagonists in the Biological Control of E. amylovora. Acta Horticulturae, 411, 297. http://dx.doi.org/10.17660/ActaHortic.1996.411.59

[20] Lindow, S.E., McGourty, G. and Elkins, R. (1996) Interactions of Antibiotics with Pseudomonas fluorescens Strain A506 in the Control of Fire Blight and Frost Injury to Pear. Phytopathology, 86, 841-848. http://dx.doi.org/10.1094/Phyto-86-841

[21] Smits, T., Rezzonico, F., Kamber, T., Blom, J., Goesmann, A., Frey, E. and Duffy, B. (2010) Complete Genome Sequence of the Fire Blight Pathogen Erwinia amylovora CFBP 1430 and Comparison to Other Erwinia spp. Molecular Plant-Microbe Interactions, 23, 384-393. http://dx.doi.org/10.1094/MPMI-23-4-0384

[22] Ngugi, H., Lehman, B.L. and Madden, L.V. (2011) Multiple Treatment Meta-Analysis of Products Evaluated for Control of Fire Blight in the Eastern United States. Phytopathology, 101, 512-522. http://dx.doi.org/10.1094/PHYTO-08-10-0221

[23] Sundin, G.W., Werner, N.A., Yoder, K.S. and Aldwinckle, H.S. (2009) Field Evaluation of Biological Control of Fire Blight in the Eastern United States. Plant Disease, 93, 386-394. http://dx.doi.org/10.1094/PDIS-93-4-0386

[24] Montesinos, E. and Bonaterra, A. (2009) Microbial Pesticides. In: Schaechter, M., Ed., Encyclopedia of Microbiology, 3rd Edition, Elsevier, Amsterdam, 110-120. http://dx.doi.org/10.1016/b978-012373944-5.00125-5

[25] Egorov, N.S. (1985) Antibiotics: A Scientific Approach. Mir Publishers, Moscow.

[26] Crawley, M.J. (1995) Methods in Ecology: GLIM for Ecologists. Oxford Blackwell Scientific Publications, London.

[27] Jock, S. and Geider, K. (2004) Molecular Differentiation of Erwinia amylovora Strains from North America and of Two Asian Pear Pathogens by Analyses of PFGE Patterns and hrpN Genes. Environmental Microbiology, 6, 480-490. http://dx.doi.org/10.1111/j.1462-2920.2004.00583.x

[28] Rothrock, C.S. and Gottlieb, D. (1984) Role of Antibiosis in Antagonism of Streptomyces hygroscopicus var. Geldans to Rhizoctonia solani in Soil. Canadian Journal of Microbiology, 30, 1440-1447. http://dx.doi.org/10.1139/m84-230

[29] Goodfellow, M., Williams, S.T. and Mordaski, M. (1988) Actinomycetes in Biotechnology. Academic Press, London.

[30] Lehr, N.A., Schrey, S.D., Hampp, R. and Tarkka, M.T. (2008) Root Inoculation with a Forest Soil Streptomycete Leads to Locally and Systemically Increased Resistance against Phytopa- 
thogens in Norway Spruce. New Phytologist, 177, 965-976.

http://dx.doi.org/10.1111/j.1469-8137.2007.02322.x

Submit or recommend next manuscript to SCIRP and we will provide best service for you:

Accepting pre-submission inquiries through Email, Facebook, LinkedIn, Twitter, etc. A wide selection of journals (inclusive of 9 subjects, more than 200 journals)

Providing 24-hour high-quality service

User-friendly online submission system

Fair and swift peer-review system

Efficient typesetting and proofreading procedure

Display of the result of downloads and visits, as well as the number of cited articles Maximum dissemination of your research work

Submit your manuscript at: http://papersubmission.scirp.org/ 